\title{
PERILAKU MANAJEMEN KEUANGAN PADA UMKM SENTRA KERAJINAN KAYU DI KABUPATEN DOMPU
}

\author{
Muhammad Ariadin', Teti Anggita Safitri² \\ Program Studi Manajemen, Fakultas Ekonomi, Ilmu Sosial dan Humaniora \\ Universitas Aisyiyah Yogyakarta \\ muhammadaariadin47@gmail.com ${ }^{1}$, tetianggita@unisayogya.ac.id²
}

\begin{abstract}
ABSTRAK
Perilaku manajemen keuangan menjadi salah satu konsep penting pada disiplin ilmu keuangan. Memiliki perilaku manajemen keuangan yang baik dapat membantu para pelaku UMKM untuk dapat bertanggung jawab dalam pengelolaan keuangan terhadap uang maupun asset dengan cara yang dianggap produktif. Penelitian ini bertujuan untuk mengetahui Faktor-Faktor yang Mempengaruhi Perilaku Manajemen Keuangan pada UMKM Sentra Kerajinan Kayu di Kabupaten Dompu. Penelitian ini merupakan penelitian yang bersifat kausal asosiatif dengan menggunakan analisis regresi linear berganda. Subyek penelitiannya adalah para pelaku UMKM Sentra Kerajinan Kayu di Kabupaten Dompu, sebanyak 30 UMKM. Teknik pengumpulan data menggunakan kuesioner. Uji validitas dan reliabilitas dilakukan terhadap 30 orang di luar subjek yang terdaftar sebagai UMKM Sentra Kerajinan Kayu di Kabupaten Dompu. Uji prasayarat analisis meliputi uji linearitas, uji multikolinearitas, dan uji heteroskedastisitas. Hasil penelitian menunjukkan bahwa (1) terdapat pengaruh yang signifikan Pengetahuan Keuangan terhadap Perilaku Manajemen Keuangan, hasil tersebut menunjukkan bahwa hipotesis ke-1 diterima, (2) terdapat pengaruh yang signifikan Pendapatan terhadap Perilaku Manajemen Keuangan, hasil tersebut menunjukkan bahwa hipotesis ke-2 diterima, (3) terdapat pengaruh yang signifikan Sikap Keuangan terhadap Perilaku Manajemen Keuangan, hasil tersebut menunjukkan bahwa hipotesis ke-3 diterima, (4) tidak terdapat pengaruh yang signifikan Kepribadian terhadap Perilaku Manajemen Keuangan, hasil tersebut menunjukkan bahwa hipotesis ke-4 ditolak, (5) terdapat pengaruh yang signifikan Pengetahuan Keuangan, Pendapatan, Sikap Keuangan, dan Kepribadian secara simultan terhadap Perilaku Manajemen Keuangan, hal ini menunjukkan bahwa hipotesis ke-5 diterima.
\end{abstract}

Kata kunci: Perilaku, Manajemen, Keuangan

\section{PENDAHULUAN}

UMKM telah lama dipahami memiliki peran yang signifikan bagi pembangunan ekonomi suatu negara. Secara spesifik, keberadaan UMKM dipercaya akan mampu berkontribusi terhadap upaya pengentasan kemiskinan melalui penciptaan lapangan kerja (Aribawa, 2016). Otoritas Jasa Keuangan (2016) melalui literasi dan inklusi keuangan 
menyebutkan bahwa kontribusi sektor UMKM di Indonesia terbukti sangat signifikan bagi perekonomian nasional dengan menyumbang 60\% Produk Domestik Bruto (PDB) dan menyerap $97 \%$ tenaga kerja nasional. Pentingnya peranan sektor UMKM dalam mendukung pertumbuhan perekonomian tersebut mengharuskan dilakukannya penguatan kapasitas UMKM. Salah satu bentuk penguatan tersebut adalah dengan meningkatkan kemampuan UMKM dalam mengelola keuangan serta memperluas akses keuangan bagi UMKM.

Fakta yang terjadi saat ini adalah UMKM seringkali mengalami keterlambatan dalam bersaing dengan perusahaan-perusahaan besar. Keterlambatan tersebut diakibatkan oleh berbagai masalah yang dihadapi, di antaranya yaitu masalah konvensional yang tidak terselesaikan secara tuntas seperti masalah kapasitas sumber daya manusia, kepemilikan, pembiayaan, pemasaran dan berbagai masalah lain yang berhubungan dengan pengelolaan usaha (Rahayu \& Musdholifah, 2017). Sehingga dukungan dan dorongan penuh dari pemerintah menjadi sangat penting untuk bisa bersaing dengan perusahaanperusahaan besar baik dalam maupun luar negeri.

Humaira \& Sagoro (2018) menyatakan bahwa kemampuan UMKM perlu diberdayakan dan dikembangkan secara terus-menerus dengan berusaha mengatasi kendala yang dialami UMKM. Diantara beberapa masalah tersebut salah satunya adalah masalah perilaku manajemen keuangan. Perilaku manajemen keuangan menjadi salah satu konsep penting pada disiplin ilmu keuangan. Maharani (2016) mendefinisikan perilaku manajemen keuangan merupakan kemampuan individu untuk dapat bertanggung jawab dalam pengelolaan keuangan terhadap uang maupun aset dengan cara yang dianggap produktif. Pada dasarnya perilaku manajemen keuangan muncul karena adanya keinginan untuk melakukan pemenuhan kebutuhan yang berdasarkan pada pendapatan yang diperoleh. Individu yang memiliki perilaku manajemen keuangan cenderung membuat anggaran, mengontrol belanja, hemat, serta bertanggung jawab terhadap uang yang dimilikinya.

Perlu adanya upaya-upaya strategis guna meningkatkan pertumbuhan bagi para pelaku UMKM. Salah satunya yakni dengan memperkaya pengetahuan keuangan yang dimiliki sehingga pengelolaan keuangan usaha dapat berkembang dengan baik (Rahayu \& Musdholifah, 2017). Pengetahuan keuangan didefinisikan sebagai kemampuan seseorang dalam memahami mengenai bagaimana cara mengatur, mengelola dan merespon risiko dari sumber daya keuangan dalam mencapai keputusan keuangan yang baik, dan dapat diperoleh baik dari latar belakang pendidikan maupun lingkungan sekitar (Triani \& Wahdaniwati, 2019). Menurut Herdjiono \& Damanik (2016) pengetahuan keuangan merujuk pada apa yang diketahui oleh individu tentang masalah keuangan pribadi, kemudian diukur dengan tingkat pengetahuan mereka dari berbagai konsep keuangan pribadi.

Pengetahuan keuangan terdiri dari keterampilan keuangan (financial skill) dan penguasaan alat keuangan (financial tools). Ida dan Dwinta (2010) dalam Humaira \& Sagoro (2018) menjelaskan bahwa keterampilan keuangan menjadi sebuah teknik untuk membuat keputusan dalam perilaku manajemen keuangan, seperti menyiapkan sebuah anggaran, berinvestasi, memilih asuransi, dan menggunakan kredit. Sementara alat keuangan adalah sarana yang digunakan dalam pembuatan keputusan manajemen keuangan, seperti cek kartu kredit dan kartu debit.

Faktor utama yang menjadi permasalahan dalam hal keterampilan keuangan yang dialami oleh para pelaku UMKM adalah dalam hal menyiapkan anggaran keuangan dalam manajemen usahanya. Hal tersebut disebabkan oleh minimnya pengetahuan 
keuangan yang dimiliki oleh para pelaku UMKM, sehingga para pelaku UMKM merasa kesulitan dalam menyiapkan dan memperoleh anggaran ketika mengelola usaha yang dijalankannya (Nisa et al., 2020).

Permasalahan kedua yang menjadi masalah dalam hal keterampilan keuangan selanjutnya yaitu yang berkaitan dengan investasi. Berdasarkan wawancara yang dilakukan ternyata tidak banyak para pelaku UMKM yang terjun ke dunia investasi. Hal ini terjadi karena rendahnya minat pelaku UMKM untuk berinvestasi dikarenakan para pelaku UMKM tidak cukup paham dan bahkan tidak tahu mengenai apa itu investasi. Hal tersebut mengindikasikan bahwa pengetahuan para pelaku UMKM mengenai investasi masih sangat rendah.

Permasalahan keterampilan keuangan tidak hanya berkaitan dengan menyiapkan anggaran dan investasi saja, tetapi kredit pun menjadi kendala bagi para pelaku UMKM. Pengetahuan mengenai kredit para pelaku UMKM masih sangat rendah. Kurangnya pengetahuan dan pemahaman para pelaku UMKM menjadi faktor yang mempengaruhi kelayakan kredit sehingga membuat para pelaku UMKM sulit untuk memperoleh modal. Selain itu banyaknya para pelaku UMKM yang tidak melakukan berbagai pertimbangan pada saat mengajukan kredit, di antaranya seperti pertimbangan tingkat bunga pinjaman dan jangka waktu pinjaman.

Faktor kedua yang dapat mempengaruhi perilaku manajemen keuangan adalah pendapatan. Pendapatan merupakan pertambahan atau peningkatan dari seluruh transaksi yang bersifat distributif dan diterima oleh individu maupun keluarga pada periode tertentu. Pendapatan yang didapatkan bukan hanya dari gaji atau upah melainkan dari bonus dan komisi, tunjangan anak, beasiswa, bantuan publik serta penghasilan yang lainnya. Menurut Andartika (2018) pendapatan merupakan besarnya jumlah uang yang didapatkan oleh seseorang dari hasil usaha maupun kinerjanya. Pendapatan bertujuan untuk membantu para pekerja dalam memenuhi kebutuhannya selama periode tertentu.

Era globalisasi membawa peningkatan dan pertumbuhan perekonomian di seluruh negara di dunia, tak terkecuali negara Indonesia. Indonesia memberikan pengaruh terhadap perilaku manajemen keuangan pada masyarakat dalam memenuhi kebutuhannya. Menurut Herlindawati (2017), sebagai manusia yang tak terlepas dari kebutuhan serta keinginan yang tidak terbatas inilah yang menjadikan salah satu faktor penyebab seseorang untuk bergaya hidup konsumtif. Pola hidup konsumtif dapat menyebabkan kegagalan financial apabila tidak diimbangi dengan perilaku konsumsi yang sesuai dengan pendapatan yang diperoleh. Hal ini juga dapat terjadi pada para pelaku UMKM. Kurangnya perilaku manajemen keuangan memungkinkan terjadinya kegagalan keuangan. Kondisi tersebut mengharuskan adanya kemampuan bagi para pelaku UMKM dalam mengelola keuangannya untuk dapat mengatur dan mengelola antara pengeluaran yang sudah dianggarkan dengan pendapatan yang diperoleh.

Faktor ketiga yang mempengaruhi perilaku manajemen keuangan adalah sikap keuangan. Sikap keuangan dapat menghadirkan sifat dan perilaku keserakahan bila digunakan dengan cara yang salah. Rahmayanti et al. (2019) menjelaskan bahwa sikap keuangan merupakan konsep dari sebuah informasi dan emosi tentang proses pembelajaran dan hasil kecenderungan untuk bertindak positif. Menurut Amanah et al., (2016) sikap keuangan diartikan sebagai keadaan pikiran, pendapat maupun penilaian individu terhadap keuangan pribadinya yang diaplikasikan ke dalam sikap.

Sikap keuangan bagi para pelaku UMKM dapat dilihat berdasarkan sudut pandang psikologi seseorang ketika melakukan penilaian terhadap praktik manajemen keuangan sehingga menjadi prinsip dalam melakukan pengambilan keputusan keuangan (Maharani, 
2016). Pelaku UMKM yang memiliki sikap keuangan dapat diketahui bagaimana kepribadiannya ketika melakukan praktik manajemen keuangan yang baik untuk masa yang akan datang. Maka dari itu, sikap dalam pengelolaan keuangan yang baik dapat dimulai dengan mengaplikasikan sikap keuangan yang baik pula.

Kemudian faktor keempat yang dapat mempengaruhi perilaku manajemen keuangan selain pengetahuan keuangan, pendapatan dan sikap keuangan yakni kepribadian seseorang. Kepribadian atau personality menurut Feist \& Feist (2017) adalah suatu pola watak yang relatif permanen, dan sebuah karakter unik yang memberikan konsistensi sekaligus individualitas bagi perilaku seseorang. Dalam memahami aspek kepribadian, Djou (2019) menjelaskan bahwa dalam mengelola keuangan dibutuhkan untuk sukses dalam mengelola keuangan, karena setiap tipe kepribadian berbeda-beda dalam cara mengelola keuangannya. Aspek kepribadian seringkali mempengaruhi manajemen keuangan karena menjadi penyebab manajemen yang buruk. Dengan mengacu pada temuan-temuan sebelumnya, dipahami bahwa kepribadian seseorang merupakan salah satu indikator yang dapat mempengaruhi perilaku manajemen keuangan.

Dompu merupakan salah satu kabupaten yang berada di Provinsi Nusa Tenggara Barat, Indonesia. Kabupaten ini berada di bagian tengah Pulau Sumbawa. Wilayahnya seluas 2.321,55 km² dengan jumlah penduduk sekitar 218.000 jiwa. Kabupaten Dompu berbatasan dengan Kabupaten Sumbawa dan Teluk Saleh di barat, Kabupaten Bima di utara dan timur serta Samudera Hindia di selatan.

Mayoritas dari masyarakat Dompu banyak berprofesi sebagai petani di tanah kering sebagai mata pencahariannya dan sudah berlangsung secara turun-temurun. Selain berprofesi sebagai petani, ada juga yang berprofesi sebagai pengrajin, buruh, wiraswasta dan lain sebagainya. Kabupaten Dompu memiliki beberapa sentra kriya yang tersebar di beberapa wilayah seperti di Kecamatan Manggelewa, Woja, Dompu dan Hu'u. Salah satunya yaitu Sentra Kerajinan Kayu.

Sentra Kerajinan Kayu merupakan kerajinan yang memanfaatkan kayu sebagai media untuk proses produksinya. Proses produksi dengan media kayu ini sangat membutuhkan kemampuan yang lebih untuk dapat menghasilkan karya yang baik dan bermanfaat supaya banyak digemari oleh konsumen. Sentra Kerajinan Kayu ini tersebar di beberapa wilayah di Kabupaten Dompu yakni Kecamatan Woja, Kecamatan Manggelewa, Kecamatan Dompu dan Kecamatan Hu'u. Rata-rata, hampir seluruh usaha di kawasan ini adalah UMKM yang memiliki potensi besar dalam meningkatkan kemajuan industri kecil maupun menengah. Para pelaku UMKM ini merupakan UMKM yang berkembang dan maju. Akan tetapi, mereka belum maksimal dalam melakukan pengelolaan keuangannya yang berkaitan dengan pengetahuan keuangan dan sikap keuangan yang baik sehingga berdampak pada perilaku manajemen keuangan yang buruk.

Dari latar belakang masalah di atas, peneliti tertarik untuk melakukan penelitian tentang Perilaku Manajemen Keuangan pada pelaku UMKM khususnya di Sentra Kerajinan Kayu di Kabupaten Dompu, Nusa Tenggara Barat. Melalui penelitian ini peneliti mengangkat penelitian yang berjudul "Faktor-Faktor yang Mempengaruhi Perilaku Manajemen Keuangan pada UMKM Sentra Kerajinan Kayu di Kabupaten Dompu." 
Jurnal Among Makarti Vol. 14 No. 1- Tahun 2021 I 35

\section{LANDASAN TEORI DAN PENGEMBANGAN HIPOTESIS}

\section{Landasan Teori}

1) Pengetahuan keuangan

Pengetahuan keuangan adalah kemampuan individu terhadap hal-hal yang berkaitan dengan dunia keuangan. Ketika individu tersebut memiliki pengetahuan yang tinggi maka individu tersebut akan menunjukkan perilaku keuangan yang lebih bertanggung jawab (Herleni \& Tasman, 2019). Individu yang memiliki pengetahuan keuangan akan lebih memahami dalam mengatur keuangannya. Semakin tinggi pengetahuan tentang keuangan maka semakin baik pula seseorang dalam mengatur keuangannya. Selain dapat membuat seseorang menggunakan uang dengan bijak, pengetahuan keuangan juga dapat memberikan manfaat terhadap ekonomi suatu negara (Widyaningrum \& Kurniawati, 2018).

Pengetahuan keuangan terdiri dari keterampilan keuangan (financial skill) dan penguasaan alat keuangan (financial tools). Ida dan Dwinta (2010) dalam Humaira \& Sagoro (2018) menjelaskan bahwa keterampilan keuangan menjadi sebuah teknik untuk membuat keputusan dalam perilaku manajemen keuangan, seperti menyiapkan sebuah anggaran, berinvestasi, memilih asuransi, dan menggunakan kredit merupakan contoh dari keterampilan keuangan. Sementara alat keuangan adalah sarana yang digunakan dalam pembuatan keputusan manajemen keuangan, seperti cek kartu kredit dan kartu debit.

2) Pendapatan

Pendapatan merupakan besarnya jumlah uang yang didapatkan oleh seseorang yakni hasil dari usaha maupun kinerjanya. Pendapatan bertujuan untuk membantu para pekerja dalam memenuhi kebutuhannya selama periode tertentu (Andartika, 2018). Menurut Purwidianti \& Mudjiyanti (2016), pendapatan didasarkan pada pendapatan dari semua sumber. Namun, komponen terbesar dari total pendapatan yakni upah dan gaji. Ada banyak kategori pendapatan yang bukan hanya dari gaji maupun upah di antaranya yaitu pendapatan sewa, bunga, dividen serta pendapatan yang lainnya.

3) Sikap Keuangan

Sikap merujuk pada bagaimana individu menyadari tentang masalah keuangan pribadi, yang diukur dengan tanggapan atas sebuah opini atau pernyataan. Sikap keuangan adalah sebagai keadaan pikiran, pendapat dan penilaian tentang keuangan (Herdjiono \& Damanik, 2016). Yuningsih et al. (2017) menyatakan bahwa sikap keuangan merupakan suatu konsep informasi dan emosi terkait proses pembelajaran dan hasil kecenderungan untuk bertindak positif. Kemudian Prihastuty \& Rahayuningsih (2018) menjelaskan bahwa sikap keuangan merupakan ukuran keadaan pikiran yang dapat dipertimbangkan dengan melihat berdasarkan sudut pandang psikologi seseorang ketika melakukan penilaian terhadap praktik dari manajemen keuangan, sehingga menjadi prinsip dalam keuangan untuk menciptakan dan memelihara nilai dalam pengambilan keputusan keuangan.

4) Kepribadian

Kepribadian atau personality menurut Feist \& Feist (2017) adalah suatu pola watak yang relatif permanen, dan sebuah karakter unik yang memberikan konsistensi sekaligus individualitas bagi perilaku seseorang. Sedangkan menurut Erich Fromm dalam Humaira \& Sagoro (2018) kepribadian adalah keseluruhan kualitas psikis yang diwarisi atau diperoleh yang khas pada seseorang yang membuatnya unik. 
Kepribadian menunjukkan struktur dan kecenderungan dalam diri orang yang menjelaskan pola karakteristik mereka dalam pemikiran, emosi dan perilaku. Kepribadian individual melekat pada seseorang yang sifatnya dapat berubah-ubah atau stabil. Seseorang sejak dilahirkan telah mempunyai karakteristik fisik dan mental yang bersumber dari orang tuanya. Karakter tersebut merupakan ciri atau sifat yang menunjukan indentitas seseorang. walaupun tidak mudah, karakteristik tersebut dapat berubah karena interaksi dengan lingkungan sekitar. Apabila lingkungan yang mempengaruhi sifat positif, maka akan berkembang kepribadian yang semakin baik demikian pula sebaliknya (Sumantri \& Gemina, 2015).

5) Perilaku Manajemen Keuangan

Perilaku manajemen keuangan menjadi salah satu konsep penting pada disiplin ilmu keuangan. Perilaku manajemen keuangan merupakan perilaku seseorang dalam mengatur keuangan mereka yang dilihat dari sudut pandang psikologi dan kebiasaan individu Humaira \& Sagoro (2018).

Menurut Rachmiyantono (2019) perilaku manajemen keuangan merupakan proses meramalkan, mengumpulkan, mengeluarkan, menginvestasikan dan merencanakan kas yang diperlukan oleh perusahaan atau individu agar dapat beroperasi dengan lancar. Perilaku manajemen keuangan juga merupakan salah satu kompetensi yang paling mendasar yang dibutuhkan oleh masyarakat modern karena pilihan konsumen dari hari ke hari akan mempengaruhi keamanan keuangan dan standar hidup seseorang.

Kemudian Novianti et al. (2016) mendefinisikan perilaku manajemen keuangan adalah kemampuan seseorang dalam mengatur perencanaan, penganggaran, pengelolaan, pengendalian, pemeriksaan, pencarian dan penyimpanan dana keuangan. Pemicu munculnya perilaku manajemen keuangan disebabkan oleh dampak dari besarnya hasrat individu dalam memenuhi kebutuhan hidupnya sesuai dengan tingkat pendapatan yang diperoleh.

\section{Pengembangan Hipotesis}

Berdasarkan penjelasan mengenai kerangka konseptual di atas, maka hipotesis penelitian yang diajukan sebagai jawaban sementara terhadap rumusan masalah penelitian ini adalah sebagai berikut:

$\mathrm{H}_{1}$ : Terdapat pengaruh signifikan pegetahuan keuangan terhadap perilaku manajemen keuangan pada pelaku UMKM.

$\mathrm{H}_{2}$ : Terdapat pengaruh signifikan pendapatan terhadap perilaku manajemen keuangan pada pelaku UMKM.

$\mathrm{H}_{3}$ : Terdapat pengaruh signifikan sikap keuangan terhadap perilaku manajemen keuangan pada pelaku UMKM

$\mathrm{H}_{4}$ : Terdapat pengaruh signifikan kepribadian terhadap perilaku manajemen keuangan pada pelaku UMKM

$\mathrm{H}_{5}$ : Terdapat pengaruh signifikan pengetahuan keuangan, pendapatan, sikap keuangan, dan kepribadian secara simultan terhadap perilaku manajemen keuangan pada pelaku UMKM.

\section{MODEL PENELITIAN}

Sama hal nya dengan pengetahuan keuangan, pendapatan, dan sikap keuangan, kepribadian juga memiliki pengaruh yang sangat signifikan terhadap perilaku manajemen keuangan. Memahami aspek kepribadian, dibutuhkan untuk sukses dalam mengelola 
keuangan karena setiap tipe kepribadian berbeda-beda dalam cara mengelola keuangannya. Sehingga dalam hal ini, individu yang memiliki pengetahuan keuangan, pendapatan, sikap keuangan dan kepribadian yang baik secara bersama-sama (simultan) akan berpengaruh terhadap perilaku manajemen keuangan untuk melakukan pengelolaan keuangan secara lebih bijaksana.

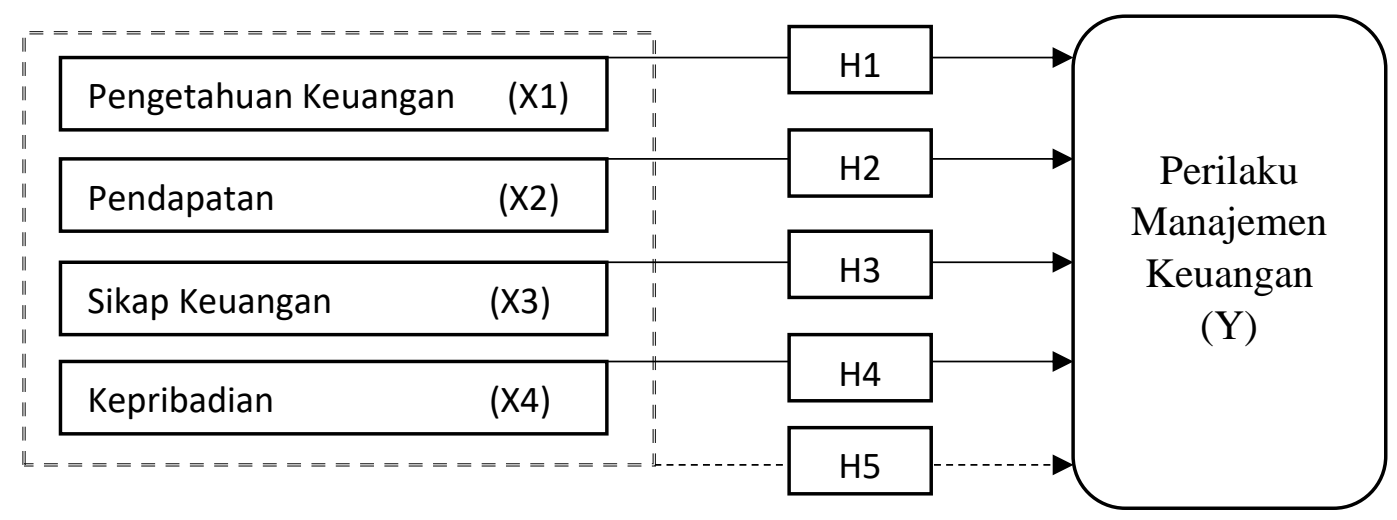

\section{Gambar 1 Model Penelitian}

Keterangan:

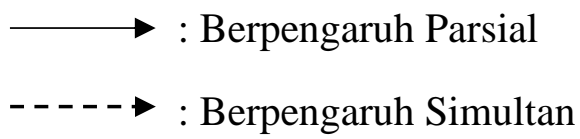

\section{METODE PENELITIAN}

Penelitian ini merupakan penelitian yang bersifat kausal asosiatif (causal assosiative research). Menurut Sugiyono (2019), penelitian asosiatif merupakan jenis penelitian yang bersifat menanyakan hubungan antara dua variabel atau lebih. Penelitian ini mengambil bentuk hubungan kausal, yaitu pola hubungan yang bersifat sebab akibat. Sumber data yang digunakan di dalam penelitian ini adalah data primer atau data yang diperoleh secara langsung dari responden. Adapun jenis data yang digunakan adalah data kuantitatif, karena data yang disajikan berhubungan dengan angka. Penelitian kuantitatif adalah metode penelitian yang berlandaskan pada filsafat positivisme, digunakan untuk meneliti pada populasi atau sampel tertentu (Sugiyono, 2019). Penelitian ini bertujuan untuk menguji pengaruh variabel independen (bebas) yaitu Pengetahuan Keuangan, Pendapatan, Sikap Keuangan, dan Kepribadian terhadap variabel dependen (terikat) yaitu Perilaku Manajemen Keuangan. 


\section{HASIL PENELITIAN DAN PEMBAHASAN}

\section{Hasil Uji Prasyarat Analisis}

\section{Uji Linearitas}

\section{Tabel 1 : Hasil Uji Linearitas}

\begin{tabular}{ccc}
\hline Variabel & Signifikansi & Keterangan \\
\hline $\mathrm{X} 1 * \mathrm{Y}$ & $0,631>0,05$ & Linear \\
$\mathrm{X} 2 * \mathrm{Y}$ & $0,942>0,05$ & Linear \\
$\mathrm{X} 3 * \mathrm{Y}$ & $0,704>0,05$ & Linear \\
$\mathrm{X} 4 * \mathrm{Y}$ & $0,946>0,05$ & Linear \\
\hline
\end{tabular}

Hasil uji linearitas pada tabel 1 diatas menunjukkan bahwa seluruh variabel tersebut memiliki nilai signifikansi lebih besar dari 0,05 yaitu $0,631,0,942,0,704$ dan 0,946 . Hal ini menunjukkan bahwa seluruh variabel tersebut linear.

\section{Uji Multikolinearitas}

Tabel 2 : Hasil Uji Multikolinearitas

\begin{tabular}{lcc}
\hline \multicolumn{1}{c}{ Variabel } & Tolerance & VIF \\
\hline Pengetahuan Keuangan & 0,973 & 1,028 \\
Pendapatan & 0,850 & 1,176 \\
Sikap Keuangan & 0,966 & 1,035 \\
Kepribadian & 0,843 & 1,187 \\
\hline
\end{tabular}

Hasil uji multikolinearitas pada tabel 2 diatas terlihat bahwa nilai Tolerance pada variabel X1, X2, X3 dan X4 lebih besar dari 0,1. Sementara nilai VIF pada variabel X1, $\mathrm{X} 2$, X3 dan X4 lebih kecil dari 10, sehingga dapat disimpulkan tidak terjadi Multikolinearitas.

\section{Uji Heteroskedastisitas}

Tabel 3 : Hasil Uji Heteroskedastisitas

\begin{tabular}{lc}
\hline \multicolumn{1}{c}{ Variabel } & Sig. \\
\hline Pengetahuan Keuangan & $0,850>0,05$ \\
Pendapatan & $0,563>0,05$ \\
Sikap Keuangan & $0,362>0,05$ \\
Kepribadian & $0,563>0,05$ \\
\hline
\end{tabular}

Hasil uji heteroskedastisitas pada tabel 3 diatas menunjukkan bahwa seluruh variabel tersebut memiliki nilai signifikansi lebih besar dari 0,05 yaitu $0,850,0,563,0,362$ dan 0,563. Hal ini menunjukkan bahwa seluruh variabel tersebut tidak terjadi heteroskedastisitas. 


\section{Hasil Uji Hipotesis dan Pembahasan}

\section{Analisis Regresi Linear Berganda}

Tabel 4 : Hasil Analisis Regresi Linear Berganda

\begin{tabular}{|c|c|c|c|c|c|}
\hline \multicolumn{6}{|c|}{ Coefficients $^{\mathbf{a}}$} \\
\hline \multirow[t]{2}{*}{ Model } & \multicolumn{2}{|c|}{$\begin{array}{c}\text { Unstandardized } \\
\text { Coefficients }\end{array}$} & \multirow{2}{*}{$\begin{array}{c}\begin{array}{c}\text { Standardized } \\
\text { Coefficients }\end{array} \\
\text { Beta } \\
\end{array}$} & \multirow[b]{2}{*}{$\mathbf{t}$} & \multirow[b]{2}{*}{ Sig. } \\
\hline & B & Std. Error & & & \\
\hline (Constant) & 80.762 & 8.437 & & 9.572 & 0.000 \\
\hline Pengetahuan Keuangan & 1.258 & 0.183 & 0.762 & 6.877 & 0.000 \\
\hline Pendapatan & 0.612 & 0.219 & 0.331 & 2.792 & 0.010 \\
\hline Sikap Keuangan & 0.368 & 0.160 & 0.257 & 2.607 & 0.020 \\
\hline Kepribadian & 0.168 & 0.167 & 0.120 & 1.006 & 0.324 \\
\hline
\end{tabular}

a. Dependent Variable: Perilaku Manajemen Keuangan

Berdasarkan hasil perhitungan, diperoleh bentuk persamaan regresi linear berganda sebagai berikut:

$$
Y=80,762+1,258 X 1+0,612 X 2+0,368 X 3+0,168 X 4
$$

Y adalah Perilaku Manajemen Keuangan, X1 adalah Pengetahuan Keuangan, X2 adalah Pendapatan, X3 adalah Sikap Keuangan, dan X4 adalah Kepribadian. Berdasarkan persamaan diatas dapat diinterpretasikan sebagai berikut:

1) Nilai konstanta sebesar 80,762 yang berarti bahwa jika variabel terikat (Perilaku Manajemen Keuangan) tidak dipengaruhi oleh keempat variabel bebas yaitu X1, $\mathrm{X} 2, \mathrm{X} 3, \mathrm{X} 4=0$, Maka besarnya rata-rata Perilaku Manajemen Keuangan bernilai 80,762 .

2) Nilai koefisien dari variabel Pengetahuan Keuangan sebesar 1,258 yang berarti, apabila Pengetahuan Keuangan pelaku UMKM (X1) meningkat 1 poin maka Perilaku Manajemen Keuangan (Y) akan meningkat sebesar 1,258 poin. Dengan kata lain, persamaan tersebut memberikan gambaran bahwa apabila Pengetahuan Keuangan pelaku UMKM meningkat 1 poin atau semakin baik, akan meningkatkan Perilaku Manajemen Keuangan pada pelaku UMKM Sentra Kerajinan Kayu sebesar 1,258 poin.

3) Nilai koefisien dari variabel Pendapatan sebesar 0,612 yang berarti, apabila Pendapatan pelaku UMKM (X2) meningkat 1 poin maka Perilaku Manajemen Keuangan (Y) akan meningkat sebesar 0,612 poin. Dengan kata lain, persamaan tersebut memberikan gambaran bahwa apabila Pendapatan pelaku UMKM meningkat 1 poin atau semakin baik, akan meningkatkan Perilaku Manajemen Keuangan pada pelaku UMKM Sentra Kerajinan Kayu sebesar 0,612 poin.

4) Nilai koefisien dari variabel Sikap Keuangan sebesar 0,368 yang berarti, apabila Sikap Keuangan pelaku UMKM (X3) meningkat 1 poin maka Perilaku Manajemen Keuangan (Y) akan meningkat sebesar 0,368 poin. Dengan kata lain, persamaan tersebut memberikan gambaran bahwa apabila Sikap Keuangan pelaku UMK M meningkat 1 poin atau semakin baik, akan meningkatkan Perilaku Manajemen Keuangan pada pelaku UMKM Sentra Kerajinan Kayu sebesar 0,368 poin.

5) Nilai koefisien dari variabel Kepribadian sebesar 0,168 yang berarti, apabila Kepribadian pelaku UMKM (X4) meningkat 1 poin maka Perilaku Manajemen Keuangan (Y) akan meningkat sebesar 0,168 poin. Dengan kata lain, persamaan tersebut memberikan gambaran bahwa apabila Kepribadian pelaku UMKM 
meningkat 1 poin atau semakin baik, akan meningkatkan Perilaku Manajemen

Keuangan pada pelaku UMKM Sentra Kerajinan Kayu sebesar 0,168 poin.

Koefisien Determinasi (R Square)

Tabel 5 : Hasil Koefisien Determinasi (R Square)

\begin{tabular}{ccccc}
\hline Model & R & R Square & Adj.R Square & Std. Error of the Estimate \\
\hline 1 & $.837^{\mathrm{a}}$ & .701 & .654 & 3.231 \\
\hline
\end{tabular}

Berdasarkan hasil analisis data dengan menggunakan program pengolah data statistik menunjukkan Adjuted R Square sebesar 0,654, yang berarti bahwa persentase pengaruh variabel independen (Pengetahuan Keuangan, Pendapatan, Sikap Keuangan, dan Kepribadian) terhadap variabel dependen (Perilaku Manajemen Keuangan) yang dapat diterangkan oleh variabel independen yaitu sebesar 65,4\%. Hal ini menunjukkan bahwa masih ada 34,6\% faktor atau variabel lain diluar penelitian ini yang dimungkinkan berpengaruh terhadap Perilaku Manajemen Keuangan.

\section{Uji Statistik t (t-test)}

Tabel 6 : Hasil Uji Statistik t (t-test)

\begin{tabular}{llcc}
\hline \multicolumn{1}{c}{ Model } & t & Sig. \\
\hline 1 & (Constant) & 9.572 & 0.000 \\
Pengetahuan Keuangan & 6.877 & 0.000 \\
Pendapatan & 2.792 & 0.010 \\
Sikap Keuangan & 2.607 & 0.020 \\
& Kepribadian & 1.006 & 0.324 \\
\hline
\end{tabular}

Berdasarkan tabel di atas, jika mengacu pada tingkat signifikansi 0,025 atau 2,5\% menunjukkan bahwa variabel Pengetahuan Keuangan didapatkan nilai t hitung sebesar $6,877>\mathrm{t}$ tabel 2,059 dengan tingkat signifikansi 0,000 yang berarti $<0,025$, sehingga dapat disimpulkan bahwa terdapat pengaruh yang signifikan Pengetahuan Keuangan terhadap Perilaku Manajemen Keuangan. Variabel Pendapatan didapatkan nilai t hitung sebesar 2,792 > t tabel 2,509 dengan tingkat signifikansi 0,010 yang berarti $<0,025$, sehingga dapat disimpulkan bahwa terdapat pengaruh yang signifikan Pendapatan terhadap Perilaku Manajemen Keuangan. Variabel Sikap Keuangan didapatkan nilai t hitung sebesar 2,607 > t tabel 2,059 dengan tingkat signifikansi 0,020 yang berarti < 0,025, sehingga dapat disimpulkan bahwa terdapat pengaruh yang signifikan Sikap Keuangan terhadap Perilaku Manajemen Keuangan. Variabel Kepribadian didapatkan nilai t hitung sebesar 1,006 < t tabel 2,509 dengan tingkat signifikansi 0,324 yang berarti $>0,025$, sehingga dapat disimpulkan bahwa tidak terdapat pengaruh yang signifikan Kepribadian terhadap Perilaku Manajemen Keuangan. 


\section{Uji Statistik F (Uji Simultan)}

Tabel 7 : Hasil Uji Statistik F (Uji Simultan)

\begin{tabular}{lllll}
\hline & Model & Sum of Squares & F & Sig. \\
\hline 1 & Regression & 612.845 & 14.674 & $0.000^{\mathrm{b}}$ \\
Residual & 261.022 & & \\
Total & 873.867 & & \\
\hline
\end{tabular}

Berdasarkan tabel di atas, nilai $\mathrm{F}$ hitung lebih besar dari $\mathrm{F}$ tabel $(14,674>2,758)$ dengan tingkat signifikansi lebih kecil dari $0,05(0,000<0,05)$. Dengan demikian terdapat pengaruh yang signifikan Pengetahuan Keuangan, Pendapatan, Sikap Keuangan, dan Kepribadian secara simultan terhadap Perilaku Manajemen Keuangan.

\section{PENUTUP}

Berdasarkan hasil analisis dan pembahasan di atas, maka dapat ditarik beberapa kesimpulan berikut ini:

1) Terdapat pengaruh yang signifikan Pengetahuan Keuangan terhadap Perilaku Manajemen Keuangan pada Pelaku UMKM Sentra Kerajinan Kayu di Kabupaten Dompu. Hal tersebut dibuktikan dengan nilai t hitung lebih besar dari t tabel $(6,877$ $>2,509)$ dengan tingkat signifikansi lebih kecil dari 0,025 $(0,000<0,025)$.

2) Terdapat pengaruh yang signifikan Pendapatan terhadap Perilaku Manajemen Keuangan pada Pelaku UMKM Sentra Kerajinan Kayu di Kabupaten Dompu. Hal tersebut dibuktikan dengan nilai t hitung lebih besar dari t tabel $(2,792>2,509)$ dengan tingkat signifikansi lebih kecil dari 0,025 $(0,010>0,025)$.

3) Terdapat pengaruh yang signifikan Sikap Keuangan terhadap Perilaku Manajemen Keuangan pada Pelaku UMKM Sentra Kerajinan Kayu di Kabupaten Dompu. Hal tersebut dibuktikan dengan nilai t hitung lebih besar dari t tabel $(2,607>2,509)$ dengan tingkat signifikansi lebih kecil dari 0,025 $(0,020<0,025)$.

4) Tidak terdapat pengaruh yang signifikan Kepribadian terhadap Perilaku Manajemen Keuangan pada Pelaku UMKM Sentra Kerajinan Kayu di Kabupaten Dompu. Hal tersebut dibuktikan dengan nilai t hitung lebih kecil dari t tabel (1,006 $<2,059)$ dengan tingkat signifikansi lebih besar dari 0,025 $(0,324>0,025)$.

5) Terdapat pengaruh yang signifikan Pengetahuan Keuangan, Pendapatan, Sikap Keuangan, dan Kepribadian secara simultan terhadap Perilaku Manajemen Keuangan. Hal tersebut dibuktikan dengan nilai $\mathrm{F}$ hitung lebih besar dari $\mathrm{F}$ tabel $(14,674>2,758)$ dengan tingkat signifikansi lebih kecil dari $0,05(0,000<0,05)$.

\section{DAFTAR PUSTAKA}

Amanah, E., Rahadian, D., \& Iradianty, A. (2016). Pengaruh Financial Knowledge, Financial Attitude dan External Locus of Control Terhadap Personal Management Behavior Pada Mahasiswa S1 Universitas Telkom. E-Proceeding of Management, 3(2), 1228-1235.

Andartika, R. (2018). Pengaruh Financial Knowledge, Tingkat Pendapatan terhadap Perilaku Pengelolaan Utang dengan Self Control sebagai Variable Mediasi (Vol. 1, Issue 1).

Aribawa, D. (2016). Pengaruh literasi keuangan terhadap kinerja dan keberlangsungan 
UMKM di Jawa Tengah. Jurnal Siasat Bisnis, 20(1), 1-13. https://doi.org/10.20885/jsb.vol20.iss1.art1

Djou, L. G. (2019). Analisis pengaruh literasi keuangan, sikap keuangan dan kepribadian terhadap perilaku pengelolaan keuangan UMKM di Kabupaten Ende. Jurnal Magisma, 7(2), 1-12. http://jurnal.stiebankbpdjateng.ac.id

Feist, J., \& Feist, G. J. (2017). Teori Kepribadian. Jilid 2, 2012, 428.

Herdjiono, I., \& Damanik, L. A. (2016). Pengaruh Financial Attitude,Financial Knowledge, Parental Income Terhadap Financial Management Behavior. Jurnal Manajemen Teori Dan Terapan| Journal of Theory and Applied Management, 9(3). https://doi.org/10.20473/jmtt.v9i3.3077

Herleni, S., \& Tasman, A. (2019). Pengaruh Financial Knowledge dan Internal Locus Of Control Terhadap Personal Financial Management Behaviour Pelaku Umkm Kota Bukittinggi. Jurnal Kajian Manajemen Dan Wirausaha, 01(01), 270-275.

Herlindawati, D. (2017). PENGARUH KONTROL DIRI, JENIS KELAMIN, DAN PENDAPATAN TERHADAP PENGELOLAAN KEUANGAN PRIBADI MAHASISWA PASCASARJANA UNIVERSITAS NEGERI SURABAYA. JURNAL EKONOMI PENDIDIKAN DAN KEWIRAUSAHAAN, 3(2), 158. https://doi.org/10.26740/jepk.v3n2.p158-169

Humaira, I., \& Sagoro, E. M. (2018). Pengaruh Pengetahuan Keuangan, Sikap Keuangan, Dan Kepribadian Terhadap Perilaku Manajemen Keuangan Pada Pelaku Umkm Sentra Kerajinan Batik Kabupaten Bantul. Nominal, Barometer Riset Akuntansi Dan Manajemen, 7(1). https://doi.org/10.21831/nominal.v7i1.19363

Maharani, T. N. (2016). Pengaruh Personal Financial Literacy, Financial Attitude Terhadap Financial Management Behavior Mahasiswa S1 Fakultas Ekonomi Universitas Andalas. Universitas Andalas.

Nisa, F. K., Salim, M. A., \& Priyono, A. A. (2020). Pengaruh Pengetahuan Keuangan, Sikap Keuangan, Dan Kepribadian Terhadap Perilaku Manajemen Keuangan Pada Pelaku UMKM Ekonomi Kreatif Sub Sektor Kuliner Kabupaten Malang. E Jurnal Riset Manajemen.

Novianti, S., Tanjung, A. R., \& Darlis, E. (2016). PENGARUH LOCUS OF CONTROL, FINANCIAL KNOWLEDGE, INCOME TERHADAP FINANCIAL MANAGEMENT BEHAVIOR. JURNAL EKONOMI, 24(3), 141-152.

Otoritas Jasa Keuangan. (2016). Siaran Pers: OJK Berdayakan UMKM Melalui Literasi dan Inklusi Keuangan.

Prihastuty, D. R., \& Rahayuningsih, S. (2018). Pengaruh Financial Literacy, Financial Behavior, Financial Attitude, Dan Demografi Terhadap Perilaku Konsumtif ( Studi Pada Mahasiswa Strata I Fakultas Ekonomi Universitas 17 Agustus 1945 Surabaya ). Jurnal Hasil Penelitian LPPM Untag Surabaya.

Purwidianti, W., \& Mudjiyanti, R. (2016). Analisis Pengaruh Pengalaman Keuangan Dan Tingkat Pendapatan Terhadap Perilaku Keuangan Keluarga Di Kecamatan Purwokerto Timur. Benefit: Jurnal Manajemen Dan Bisnis, 1(2), 141. https://doi.org/10.23917/benefit.v1i2.3257

Rachmiyantono, R. (2019). Financial Knowledge Dan Locus of Control Dalam Financial 
Management (Studi Empiris Keluarga Di Kecamatan Demak Kabupaten Demak Provinsi Jawa Barat). Jurnal Ilmiah UNTAG Semarang, 8(1), 107-115.

Rahayu, A. Y., \& Musdholifah. (2017). Pengaruh literasi keuangan terhadap kinerja dan keberlanjutan umkm di kota surabaya. Jurnal Ilmu Manajemen, 5(2016), 2017.

Rahmayanti, W., Sri Nuryani, H., \& Salam, A. (2019). Pengaruh Sikap Keuangan Dan Perilaku Keuangan Terhadap Literasi Keuangan. Jurnal Manajemen Dan Bisnis, 2(1). https://doi.org/10.37673/jmb.v2i1.267

Sugiyono. (2019). Metode Penelitian Pendidikan. Bandung: Alfabeta.

Sumantri, U., \& Gemina, D. (2015). Pengaruh Faktor Kepribadian Individual, SelfEfficacy Serta Locus of Control Terhadap Kinerja Usaha Mikro Kecil Dan Menengah Di Kecamatan Caringin Kabupaten Bogor. Jurnal Visionida, 1(2), 1530.

Triani, A., \& Wahdaniwati, R. (2019). PENGARUH PENGETAHUAN KEUANGAN DAN SIKAP KEUANGAN TERHADAP PERILAKU MANAJEMEN KEUANGAN (Studi Kasus Pada Mahasiswa S1 Program Studi Manajemen Universitas Komputer Indonesia). Universitas Komputer Indonesia.

Widyaningrum, S., \& Kurniawati, S. L. (2018). Pengaruh Sikap Keuangan, Pengetahuan Keuangan Dan Pengalaman Keuangan Terhadap Perilaku Pengelolaan Keuangan Keluarga Di Sidoarjo. STIE Perbanas, 45, 39.

Yuningsih, I., Dewi, A. S., \& Gustyana, T. T. (2017). Analisis Literasi Keuangan Di Masyarakat Kota Bandung. Jurnal Neraca: Jurnal Pendidikan Dan Ilmu Ekonomi Akuntansi, 1(1). https://doi.org/10.31851/neraca.v1i1.1167 